\title{
Analyzing the Impact of Microfinance Banks Credit Variables on Micro, Small Enterprises Growth Indicators in South-West, Nigeria
}

\author{
Obadeyi J.A ${ }^{1} \quad$ Ogbeide Sunday $^{1} \quad$ Adesuyi I.O $^{2}$ \\ 1.Department of Accounting \& Finance, Elizade University, Ilara-Mokin, Ondo State \\ 2.Department of Business Administration, Elizade University, Ilara-Mokin, Ondo State
}

\begin{abstract}
Despite several reforms both in the banking and informal sectors; it is sad that there have been dwindling development in both sectors. In view of this, this study analyzed the impact of Microfinance Banks (MFBs) credit variables on Micro Small Enterprises (MSEs) growth indicators in South-West, Nigeria. Sampled MFBs, MSEs and some South-West States were purposively selected. Secondary data was extracted from financial statements of eight selected MFBs from 2007-2016 (10years). Relationship between MFBs variables and MSEs' growth was analyzed using Correlation matrix, while extent at which MFBs variables influenced MSEs growth was analyzed using panel regression. Results showed the relationship between MFBs credit variables and MSEs' growth with an average ' $\mathrm{r}$ ' at $68.56 \%(\mathrm{p}<0.05)$; and the extent at which MFBs credit variables influenced MSEs growth $(\mathrm{p}<0.05)$ such as profit, total asset, number of employee growth and sales with $\mathrm{R}^{2}$ were $61.4 \%, 58.3 \%, 48.1 \%$ and $52.1 \%$, respectively. The study concluded that MFBs credit variables influenced MSEs growth. It was recommended that MFBs should moderately increase loan size in order to improve MSEs' business operations.
\end{abstract}

Keywords: Microfinance Banks, Micro Small Enterprises, Credit Variables, Growth indicators, South-West, Nigeria

DOI: $10.7176 / \mathrm{RJFA} / 11-12-06$

Publication date:June 30th 2020

\section{Introduction}

Evidence from the literatures showed that microfinance bank was a financial institution closest to the grassroots and the equity was 100 percent private sector owned (Schreiner, 2002; Acha, 2007; Oladejo, 2013). The concept of microfinance banking was a self-sustaining financial institution designed for the provision of financial services to the people for the promotion of rural development (Acha, 2007). Microcredit remained a tool that enhanced economic development to the poor in the society and regarded as an important strategy used to reduce poverty among many countries across the globe. Microcredit involved an 'extremely small credit given to alleviate people in pain to help them become self-employed (Besley, 2008; Akande, 2014).

In recent years, economies of the world have a great support for Micro and Small Enterprises (MSEs) which had exponentially led to economic development. This was because of the contribution of MSEs to the employment creation. MSEs contributed to the provision of employment opportunities (Bwisa \&Wanambisi 2013; Akande, 2014; Obadeyi, 2015. MSEs held the key to possible revival of economic growth and the elimination of poverty on a sustainable basis. Despite the substantial role of the MSEs particularly in Nigeria's economy, MSEs were denied financial support, particularly micro loans from institutionalized financial service organizations, which were responsible for the provision of funds. The MFBs were regarded as the best alternative source of financing low income earners and mini business to help raise income and the ability to reduce poverty level in the economy (Muktar, 2009). The Microfinance Institutions (MFIs) have succeeded in providing opportunities; managing scarce household and enterprises resources more efficiently, protection against financial risks by taking advantages of investment opportunities and gaining economic returns (Okpara, 2010; Taiwo, Onasanya, Agwu \& Benson, 2015; Shabbir, 2016). The number of Microfinance Institutions (MFIs) serving the informal sector was at increase because at least 133 million clients had been served by averagely 3300 MFIs globally which stood at $26 \%$ during 2005-2007 financial periods (MIX, 2009). Though, the evolution of MFIs was completely different from cooperatives, self-help and informal credit groups. But since late ' 70 s, Non-Government Organizations (NGOs) had been regarded as new players to have further supported the existence and awareness of microfinance institutions globally (Vanroose, 2008).

\section{Literature Review}

\subsection{Microfinance Bank Credit Variables}

\subsubsection{Loan size}

Loan could be described as the lending of money from one entity to another, but the disbursement vary that is, disbursement could be small or large (Odongo, 2014). Rosenberg (2009) in his study, findings showed that financial institutions preferred to extend large credit because the administrative costs decreased proportionately to 
the size of the loan. Various studies (Wole Adamolekun, 1993; Odongo, 2014; Makorere, 2014; Laetitia et al, 2015) also indicated that most MSEs considered micro and small loans amount to meet immediate needs because MSEs lacked the capacity or experience to handle large sums of money in their businesses and even could lead to business failure. Loans were given depending on the level of savings performance with financial institution and the MSEs previous loan repayment. Most of these loans were lent out depending on the collection convenience, payment and flexibility with experienced clients. Financial institutions motives were to meet their clients' working capital by giving short term loans and limit long term loans. Financial institutions cite weak MSE management, lack of collateral and unreliable financial information on MSE operations as the main constraints to funding MSEs (Nguta \& Guyo, 2013).

\subsubsection{Cost of Money}

Pearson \& Greef (2006) and Makorere (2014) claimed that the cost of money was the expected amount of profit realized as a result of interest payments on available money. Nguta \& Guyo, (2013) explained that cost of money often changed viz-a-viz changes in interest rates, so as to measure opportunity costs that occurred if investment were to be on other financial assets such as shares/stocks, and bonds. Gaul (2011) argued that there was widespread agreement that most MFBs operate high costs of transaction which attracted high interest rates charged on loans and fees to cover those costs. (Besley, 2008) further asserted that in most situations MSEs ought to pursue financial sustainability by being as efficient as they could but MFBs charged high interest rate to cover the costs of their lending and other services. Warue (2012) concurred with Rosenberg (2009) that the cost of money charged to MSEs was unbearable and unreasonable to cover the costs of lending. Warue added that costs of money were excessively high which could result to poor financial performance of MSEs. There was an inverse relationship between cost of money and profitability trends of MSEs. Studies (Rosenberg, 2009; Nguta \& Guyo, 2013 and Makorere, 2014) claimed that the low cost of money could improve performance on MSEs activities resulting to increase in turnover and profit, while high cost of money would lead to stagnated performance and MSEs businesses might collapse in the short period.

\subsubsection{Credit / Loan Period}

Murray (2011) claimed that credit period was the time over which the borrower borrowed money from the lender. This then became the repayment period, over which the borrower would have to make regular repayments to ensure the loan balance was paid in full by the agreed date. Warue (2012) further claimed that credit periods for unsecured loans typically could be up to five years, while secured loans involved longer credit periods. There were many dominant factors that influenced MFBs to give short credit period for a loan to the MSEs; this might be due to high cost of resources (funds), unclear client credit history and security offered for loan (Pearson \& Greef, 2006). Mushtaque \& Mosley (2004) and David et al, (2014) opined that short credit period with high cost of funds was a mismatch as the MSEs owners could be required to make loan repayment with high interest in a shortest possible period. These high charges discouraged MSEs operators and might eventually led to poor performance of micro and small business operators. David et al, (2014) claimed that short-term loan could make MSEs not to perform well in their operations because of big installment payments to be remitted back to the MFBs in the short time like weekly, fortnight and monthly payment since the loan grew bigger in the given time with high interest rates charge. The loan period given was not suitable for MSEs' performance in the current economic crises. However, long loan period of lending to MSEs contributed positively to MSEs performance and enhanced the MSEs' business operations.

\subsubsection{Factors that influence the firm's Growth 2.1.4.1 Profitability}

According to Barbosa (2016), profitability involved the degree to which a business or activity yielded profit or financial gain. It was also a special difference between the amount earned and the amount spent in producing and distributing goods and services. Profitability referred to the operating efficiency of the enterprise. It also explained the ability of the enterprise to make profit on sales. Profitability was the ability of the company to make a profit in relation to sales, total assets and own capital (Wanjohi, and Mugure, 2008).

\subsubsection{Sales Growth}

Sales growth was defined as the amount of the average sales volume of a company's products that has increased tremendously from a particular period to another on a yearly basis. Hansen and Mowen (2012) argued that sales growth was an increase in sales from a particular year to another. Companies with increase in sales growth volume would require additional investment in the different composition of assets i.e. fixed or current asset. Though, the sales growth could easily assist the company to predict the expected profit in the future. Venkatraman and Ramanujam (1987) examined the extent of convergence among techniques measuring business performance and concluded that profit and sales growth remained a different measures of dimensions of business enterprise performance. Wanjohi, and Mugure, (2008) argued that sales growth would be represented by the percentage change in sales for each company in the sample over a single year, adjusted for the industry average.

\subsubsection{Number of Employee Growth}

Murphy, Trailer and Hill (1996) defined number of employee growth as the increase in number of persons 
employed in a firm to improve its productivity capacity; that is, the total number of people who worked in an organization. Employee growth represented the change in the number of people employed by an organization between two time periods. Murphy et al (1996), further claimed that employee growth believed to be the second best performance indicator to the use of sales growth. They added that growth in employees could be suggested as a proxy for various organizational performance indicators. This was because companies might inject additional number of employees in anticipation of coincident with, sales growth. Therefore, the development of employment remained a component of critical knowledge, having been adopted as a measure of performance (Baum, Calabrese, \& Silverman, 2000)

\subsubsection{Total Assets}

Hoff \& Stiglitz (1990) and Alex, (2014) claimed that assets were economic values that associated with items that expended over a particular period of time to generate benefit. Total asset was the final amount of all gross investments, cash, receivables, and other assets as contained in the financial statement particularly the balance sheet. Dunne \& Hughes, (1994) claimed that the ability of a firm to always attract capital was based on critical performance dimension. Therefore, growth in assets was considered as an effective measure of organizational performance. It must be noted that sales has a crucial role to manage working capital. Sales helped the firm to effectively predict expected profit to be realized in the future; while total asset growth encouraged the firm to increase its overall resources by expecting to expand and increase number of branches within and outside its primary location. The expansion and business diversification via the increase in asset attracted more labour force (employees) to manage the company. Also Rosenberg (2009) claimed that there were proxies that measure business growth in an informal market includes total sales, number of employees and total assets.

\subsection{Theoretical Framework}

\subsubsection{Theory of Microfinance Development}

Theory of Microfinance Development was popularized by Yunus Mohammad, while establishing the Grameen Bank in Bangladesh 1976. The development theory of microfinance bank used microcredits to assist people out of poverty but without providing collateral facilities. The theory propounded by Yunus concentrated in helping business people that lived in rural settlements, but who needed financial institutions (mini banks) assistance. Financial Institution that would assist in developing their social-cultural and economic lives. This led to the provision of alternative institutional frameworks that would encourage the livelihood alternatives through the availability of credits for production, distribution and investment among the people. The theory of microfinance development also claimed that less developed economies were more associated with underdevelopment, poverty, hunger and low credit opportunities because the people could not access mini credits from traditional financial institutions. However, it is of great importance to elaborate on available and targeted credit provision programmes in order to extend the outreach of lenders to provide credits to the poor people particular in the rural areas through a strong and feasible regulatory and supervisory policy guidelines. Microfinance development theory also clarified that inability of business people in rural centers to access available credits/loans had a serious negative effect on the people with poor results, which was not limited to bad nutrition, lack of information and technology, low agricultural output, dwindling production level, poor health care facilities, increase in unemployment etc. Therefore, the theory believed that availability of credits to the people would promote their standard of living and overall economy.

\subsection{Empirical Review}

According to Dunne \& Hughes (1994), sales growth was used as a proxy for firm growth in the context of five different countries. Also, Gallagher, (2006) have used growth in total assets in the context of Baltic listed companies. Guerin and Palier (2005) used the same proxy in the context of Pakistan, Kung \& Thomas (1981) in the context of China and Hansen and Mowen (2012) used growth in real assets in the context of ten developing countries. Considering the Indian context, Kazanjian \& Drazin, (1989), Hajela (2009), Hartaska (2005); these studies have adopted growth in total assets and Kibera (2012) used annual growth in sales as a proxy for growth. Liedholm (2002) examined the determinants of survival and growth of SMEs in Africa and Latin America, and concluded that firms located in urban areas were more likely to survive, while location was central features in identifying firm growth prospects. Gonzalez and Sushma, (2009) investigated the effect of economic control on firm growth, and concluded that the economic development and a healthy financial system were associated with firm growth. Gonzalez and Sushma further emphasized that there was a relationship between firm growth, banks, non-banks and financial market, and concluded that effective legal and conducive environment could protect investors' interests, promote financial sector development and encourage firm growth. Studies (Dunne \& Hughes, 1994; Mata \& Portugal, 1994; Audretsch, 1995; Yang, 2005) claimed that firms that were more capital intensive often grew faster. Tight monetary policy via the increase in the interest rate continued to encourage high cost of borrowing for firms thereby worsen the informal sector's situation to access finance, and destabilized the corporate sector. The informal sector and financial system could be significantly affected by reducing the flow of income 
available to meet current obligations and increasing uncertainty about future liquidity needs of banks. A high inflation rate could also affect the firm's ability to pay interests on its debt, thus increasing the risk of financial distress, and threatening the viability of firms (Bernanke, 1983; Wadhwani, 1986; Gordon, 1988).

\subsection{Conceptual Framework}

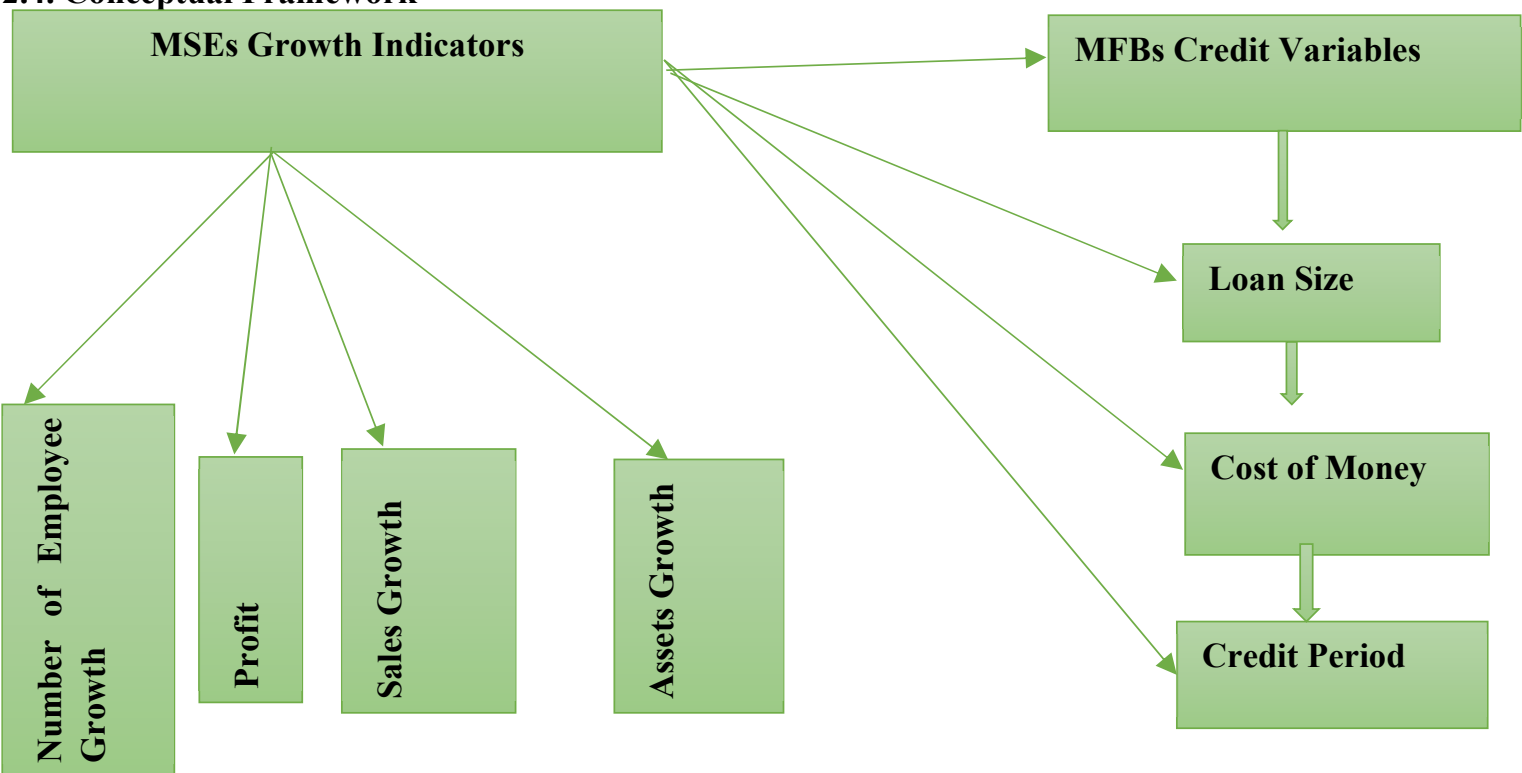

Fig-1. Analyzing the Impact of Microfinance Banks (MFBs) Credit Variables on Micro Small Enterprises Growth in South-West, Nigeria.

Source: Researchers' Compilation, (2018).

\section{Methodology}

The study adopted secondary source of data by assessing financial statements of selected MFBs. Purposive sampling technique was chosen to select the MFBs, MSEs operators and States in the South-West, Nigeria. The reason for choosing Lagos and Ogun States was because there were large numbers of MFBs concentration and their financial statements were made available for assessment. The study also used Correlation coefficient matrix model to measure the strength and direction of the linear relationship between variables, represented with ' $r$ '. Consequently, coefficient of determination measured the proportion of variability in a data which was accounted by a statistical model; often called $\mathrm{R}^{2}$ (Gujarati, 2004). Correlation coefficient as stated;

$$
r=\frac{\sum X Y-\frac{\left(\sum X\right)\left(\sum Y\right)}{n}}{\sqrt{\left(\sum X^{2}-\frac{\left(\sum X\right)^{2}}{n}\right)\left(\sum Y^{2}-\frac{\left(\sum Y\right)^{2}}{n}\right)}}
$$

$\mathrm{r}=$ correlation coefficient; $\mathrm{x}=$ independent variable; $\mathrm{Y}=$ Dependent variable; $\sum=$ Summation Hence, MSEG (MSEs Growth) $=\mathrm{f}($ Loan size, Cost of Money and Credit Period $)$

$\mathrm{MSEG}_{\mathrm{i}}=\mathrm{f}\left(\mathrm{X}_{\mathrm{i}} \ldots \mathrm{X}_{\mathrm{n}}\right)$

Where,

MSEG = dependent variable was a measure of the factors that caused MSE to grow (Number of employee growth, profit, total asset and sales growth);

$\mathrm{f}=\mathrm{a}$ function to be specified

$\mathrm{X}=$ an explanatory variables of microfinance characteristics that pertain to MFB variables.

From equation (ii) above, it can be adjusted to equation iii:

MSEG $=\beta_{0}+\beta_{1} X_{1} \ldots \ldots+, \beta_{\mathrm{n}} X_{\mathrm{n}}+\mu_{2}$

Where, $\mathrm{MSEG}=$ dependent variable (MSE Growth)

$\beta_{0}=$ intercept term

$\beta_{1}=$ partial regression coefficient

$\mathrm{X}_{1}=$ explanatory variables / regressor

$\mathrm{X}_{1},, \ldots, \ldots, \ldots, \ldots, \mathrm{X}_{\mathrm{n}}$ were slopes / independent variables (MFB variables).

(Where $\mathrm{LD}=$ Loan size, $\mathrm{CM}=$ Cost of money, $\mathrm{CP}=$ Credit period).

The predictor variables are given as $\mathrm{X}_{1}, \ldots \mathrm{X}_{3}$. 
Where

$\mathrm{X}_{1}=$ Loan size

$\mathrm{X}_{2}=$ Cost of money

$\mathrm{X}_{3}=$ Credit period

$\beta_{1}, \beta_{2}, \beta_{3}, \ldots, \ldots, \ldots, \beta_{\mathrm{n}}$ was a slope parameters or partial regression coefficients which determined the contribution of the independent variables

$\mu=$ stochastic term / Error term (which revealed the strength of $\beta_{1} X_{1} \ldots \beta_{n} X_{n}$. To determine the proportion of variation that would be explained required a measure of "goodness of fit" in regression analysis, which could otherwise be called as the coefficient of determination, $r^{2}$. It helped to measure the variation in the dependent variables accounted for the variation on the independent variables.

Therefore the equation was written newly as;

$\mathrm{MSEG}_{\mathrm{i}}=\beta_{0}+\beta_{1} \mathrm{LS}_{1}+\beta_{2} \mathrm{CM}_{2}+\beta_{3} \mathrm{CP}_{3}+\mu_{2 .}$-------------------- (iv)

\section{Result}

\subsection{Pearson Correlation Matrix Result}

This described the relationship between MFBs variables and MSEs' growth indicators. The result was displayed in table 4.1 Table 4.1 showed the Pearson Correlation matrix of the variables depicting the relationship between microfinance bank credit variables and MSEs' growth indicators such as sales, profit, total asset and number of employees growth (NOE) and cost of money, loan size and credit period respectively. It revealed that loan size shared a positive relationship with sales $(\mathrm{r}=0.6991)$, NOE $(\mathrm{r}=0.6194)$, total asset growth $(\mathrm{r}=0.5823)$ and profit $(\mathrm{r}=0.7422)$. The average correlation coefficient $(\mathrm{r})$ of loan size to MSEs growth was 0.6605 . This underlined the possibility of an increased growth made possible through moderate loan size disbursed by MFBs. The loan was part of the organization additional resources that increased turnover and earnings of MSEs. This also showed that every increase in loan size would automatically increase sales, asset, NOE and profit. The result further revealed that cost of money has a negative relationship with sales $(r=-0.5162)$, NOE $(r=-0.5686)$, total asset $(r=-0.6348)$ and profit $(\mathrm{r}=-0.4956)$. The average correlation coefficient $(\mathrm{r})$ of cost of money to MSEs growth was -0.5538 ($55.4 \%$ ). This result explained that the increase in interest rate could discourage the performance on MSEs activities and could lead to stagnated performance. While the credit period showed a positive relationship with sales $(\mathrm{r}=$ $0.5200)$, NOE $(r=0.5517)$, total asset $(r=0.6323)$ and profit $(r=0.6117)$. This result showed that an increase in credit repayment period allowed MSEs operators to achieve increase in sales, profit, asset and NOE. The result further showed that repayment period to the borrower was moderate to assist the sales performance of the enterprise. The average correlation coefficient (r) of credit period to MSEs growth was 0.578925 (58\%). Therefore, the general result showed that there was a positive relationship between MFBs and MSEs growth variables where $r=$ 0.6856 (69\%). This result corroborated with Nguta \& Guyo, (2013), Oladejo, (2013), Bwisa \& Wanambisi, (2014) and Multhoni, (2016) who opined that size of loans determined the size of profit and turnover of firms and there existed a relationship between the variables. 
Table: 4.1: Correlation Matrix

CORRELATION MATRIX

\begin{tabular}{|c|c|c|c|c|c|c|c|}
\hline $\begin{array}{l}\text { Correlation } \\
\text { Probability } \\
\end{array}$ & SALES & PROFIT & NOE & ASSET & LOAN_SI & CRE_PE & OST-M \\
\hline SALES & $\begin{array}{r}1.0000 \\
----\end{array}$ & & & & & & \\
\hline PROFIT & $\begin{array}{l}0.5330^{* *} \\
(0.0143)\end{array}$ & $\begin{array}{r}1.0000 \\
-----\end{array}$ & & & & & \\
\hline NOE & $\begin{array}{l}0.6241 * * * \\
(0.0000)\end{array}$ & $\begin{array}{l}0.6499 \\
(0.0553)\end{array}$ & $\begin{array}{r}1.0000 \\
-----\end{array}$ & & & & \\
\hline ASSET & $\begin{array}{l}0.6141 * * * \\
(0.0002)\end{array}$ & $\begin{array}{l}0.5601 \\
(0.0794)\end{array}$ & $\begin{array}{c}0.3328 * * \\
(0.0133)\end{array}$ & $\begin{array}{r}1.0000 \\
----\end{array}$ & & & \\
\hline LOAN_SIZE & $\begin{array}{l}0.6691 * * \\
(0.0305)\end{array}$ & $\begin{array}{c}0.5422 * * \\
(0.0390)\end{array}$ & $\begin{array}{c}0.6194 * * \\
(0.0267)\end{array}$ & $\begin{array}{c}0.5823 * * \\
(0.0254)\end{array}$ & $\begin{array}{r}1.0000 \\
----\end{array}$ & & \\
\hline CREDIT PERIOD & $\begin{array}{l}0.5200^{* *} \\
(0.0232)\end{array}$ & $\begin{array}{l}0.6117^{* *} \\
(0.0121)\end{array}$ & $\begin{array}{r}0.5517 * * \\
(0.0222)\end{array}$ & $\begin{array}{c}0.6323 * * \\
(0.0167)\end{array}$ & $\begin{array}{c}-0.2356^{* *} \\
(0.0321)\end{array}$ & $\begin{array}{c}1.0000 \\
---\end{array}$ & \\
\hline COST_OF_MONE & $\begin{array}{l}-0.5162^{* *} \\
(0.0214)\end{array}$ & $\begin{array}{r}-0.4956^{* *} \\
(0.0443)\end{array}$ & $\begin{array}{l}-0.5686^{* *} \\
(0.0217)\end{array}$ & $\begin{array}{c}-0.6348^{* *} \\
(0.0156)\end{array}$ & $\begin{array}{c}0.4673^{* *} \\
(0.0215)\end{array}$ & $\begin{array}{l}0.5418^{* * *} \\
(0.0001)\end{array}$ & $\begin{array}{r}1.0000 \\
---\end{array}$ \\
\hline Source: & or's & Compila & n & E- & -Views & 9.5 & (2018) \\
\hline
\end{tabular}

\subsection{Panel Regression Result on Profit.}

This described the extent of MFBs credit variables' influenced on MSEs' growth using profit as proxy. The result displayed in table 4.2. Table 4.2 showed the panel regression of the variables depicting the extent of microfinance bank credit variables proxy by cost of money, credit period and loan size influenced on MSEs' growth, adopting profit. In this section, we presented our estimates of the various hypothesized variables explaining one of the performance indicators (profit) in the study. The pooled OLS result showed a positive marginal impact of loansize with coefficient value (8.19) and credit period (2.17) but cost of money (-6.59) has a negative influence on profit performance. For every loan disbursed by MFBs, 8.19 profits would be accrued to MSEs operators for improved business performance. Also for every loan repayment period the profit would increase by 21.7 to micro and small business entrepreneurs. All the variables were statistically significant $(\mathrm{p}<0.05)$. The variables that were combined accounted for $0.614035(61.4 \%)$ of the variation in the profit as shown by the R-squared value. While the value of adjusted R -squared was 0.591237 (59\%). The Durbin Watson (DW) was 1.382144. This was closed to 2. This explained no sign of autocorrelation. While the high cost of funds would affect the performance of profit by -6.59 . This result was in tandem with Rosenberg, 2009; Warue, 2012; Nguta \& Guyo, 2013 and Makorere, 2014). They opined that low cost of money could improve performance on MSEs activities resulting to increase in turnover and profit, while high cost of money would lead to stagnated performance. The fixed effect model in column two revealed all the explanatory variables have positive coefficient values with loan-size (5.48), credit period $(0.03)$ and cost of money (0.08). All the variables were statistically significant $(\mathrm{p}<0.05) .48 \%$ of the variation experienced in the value of profit was accounted for by the bank variables. 
Table 4.2: MFBs credit variables influence on MSEs' Growth (Profit).

\begin{tabular}{lll}
\hline & \multicolumn{1}{c}{ ALL } & ALL \\
\cline { 2 - 3 } LOAN SIZE & OLS & FE \\
\cline { 2 - 3 } COST OF MONEY & $8.19 \mathrm{E}-06^{* * *}$ & $5.48 \mathrm{E} .07^{* *}$ \\
& $(1.76 \mathrm{E}-06)$ & $(1.61 \mathrm{E}-07)$ \\
CREDIT PERIOD & $-6.590040^{* * *}$ & $0.082034^{*}$ \\
& $(1.168929)$ & $(0.079560)$ \\
CONSTANT & $2.173114^{* *}$ & $0.033930^{*}$ \\
R & $(0.073591)$ & $0.004255)$ \\
OBSERVATION & & 11.68149 \\
$\mathrm{~N}$ & $\ldots \ldots \ldots \ldots \ldots$ & 0.476738 \\
\hline
\end{tabular}

\section{Source: Authors' Compilation, 2018}

Note: All independent variables are differenced to ensure stationarity and thereby avoiding spurious regression while the dependent variable profit is in log form. The level of significance is denoted as $* P<0.1, * * P<0.05$ and $* * * P<0.01$. Figure in the parentheses are (standard error).

\subsection{Panel Regression Result on Number of Employee (NOE).}

This described the extent of MFBs credit variables' influence on MSEs' growth using number of employees as proxy. The result displayed in table 4.3. Table 4.3 showed the pooled OLS with positive coefficient values of loansize (1.30), credit period (0.14) and cost of money has a negative coefficient value (-1.09) on number of employee growth. For every loan disbursed to MSEs operators, it generated 1.3 growth of employees while credit repayment period allowed for 0.14 of employee growth. Also for every interest charged by MFBs it attracted a negative -1.09 on employee growth. The reason for the negative result on cost of money $(-1.09)$ might be as a result of high interest rate charged which has affected the revenue performance of MSEs and to sustain the employees in terms of salaries and wages and other expenses incurred by micro and small business operators might be difficult or endanger (Wellen \& Mulder, 2008). Loan size was statistically significant $(p<0.05)$. Credit period was statistically significant $(\mathrm{p}<0.01)$ while cost of money was statistically significant $(\mathrm{p}<0.01)$. The variations in the number of employee growth were accounted for 0.481044 (48\%) by bank variables as shown by the R-squared value. The adjusted R-squared value was 0.442681(44.3\%). The Durbin Watson (DW) was 1.324022. This was closed to 2. This explained no sign of autocorrelation. The fixed effect model in column two revealed that coefficient values of loan size (7.61) and credit period (0.008) have positive influence on number of employees while cost of money $(-0.099)$ has negative influence on number of employee growth. Loan size was statistically significant $(p<0.05)$, credit period $(p<0.1)$ and cost of money statistically significant $(p<0.05) .60 \%$ of the variation experienced in the value of number of employees was accounted for by the bank variables.

Table 4.3: MFBs credit variables influence on MSEs' Growth (Number of Employees)

\begin{tabular}{|c|c|c|}
\hline & ALL & ALL \\
\hline & OLS & $\mathrm{FE}$ \\
\hline LOAN SIZE & $\begin{array}{l}1.30 \mathrm{E}-06^{* *} \\
(3.25 \mathrm{E}-07)\end{array}$ & $\begin{array}{l}\text { 7.61E-07*** } \\
(1.15 \mathrm{E}-06)\end{array}$ \\
\hline COST OF MONEY & $\begin{array}{c}-1.087527 * * * \\
(0.215646)\end{array}$ & $\begin{array}{l}-0.099709 \\
(1.67 \mathrm{E}-07)\end{array}$ \\
\hline CREDIT PERIOD & $\begin{array}{l}0.138103 * * \\
(0.013516)\end{array}$ & $\begin{array}{l}0.008923 \\
(8.18 \mathrm{E}-07)\end{array}$ \\
\hline CONSTANT & ............. & 0.705098 \\
\hline $\mathrm{R}^{2}$ & 0.481044 & 0.600975 \\
\hline OBSERVATION & 79 & 79 \\
\hline $\mathrm{N}$ & 8 & 8 \\
\hline
\end{tabular}

Source: Authors' Compilation, 2018

Note: All independent variables are differenced to ensure stationarity and thereby avoiding spurious regression while the dependent variable profit is in log form. The level of significance is denoted as $* P<0.1, * * P<0.05$ and $* * * P<0.01$. Figure in the parentheses are (standard error). 


\subsection{Panel Regression Result on Sales.}

This explained the extent of MFBs credit variables' influence on MSEs' growth using sales as proxy. The result was shown in table 4.4. Table 4.4 showed the pooled OLS with positive coefficient values of loan-size (8.37) and cost of money was negative (-7.53) and positive credit period (0.21) on sales growth. For every loan disbursed, it generated 8.37 turnover for MSEs operators. Also for every credit period enjoyed by the MSEs operators, 0.21 of sales would be realized while for every interest rate charged, there would be decrease in the volume of sales. Loan size was statistically significant $(\mathrm{p}<0.05)$. Credit period was statistically significant $(\mathrm{p}<0.05)$ while cost of money was statistically significant $(\mathrm{p}<0.1)$. Some of the variables were more statistically significant $\mathrm{P}<0.05$. The Durbin Watson (DW) was 1.342486. This was closed to 2. This explained no sign of autocorrelation. The variables that were combined, accounted for $0.521321(52 \%)$ of the variation in the sales performance as shown by the R-squared value. The adjusted R-squared value was $0.487351(49 \%)$. The reason for the negative result in cost of money may be due to high cost of funds thereby resulting to dwindling revenue from sales. The Random effect model in column two revealed that loan-size (4.83) positively influenced sales while credit period (-0.005) and cost of money $(-0.006)$ showing a negative coefficient values. $45 \%$ of the variation experienced in the value of sales growth was accounted for by the bank variables.

Table 4.4: MFBs credit variables influence on MSEs' Growth (Sales)

\begin{tabular}{|c|c|c|}
\hline & ALL & ALL \\
\hline & OLS & RE \\
\hline LOAN SIZE & $\begin{array}{l}8.37 \mathrm{E}-06 * * * \\
(2.07 \mathrm{E}-06)\end{array}$ & $\begin{array}{l}4.83 \mathrm{E}-07 * * \\
(1.55 \mathrm{E}-07)\end{array}$ \\
\hline CREDIT PERIOD & $\begin{array}{l}0.214279 * * \\
(0.086566)\end{array}$ & $\begin{array}{l}-0.005953 \\
(0.004147)\end{array}$ \\
\hline COST OF MONEY & $\begin{array}{l}-7.529366^{* * *} \\
(1.375039)\end{array}$ & $\begin{array}{l}-0.006991 \\
(0.077509)\end{array}$ \\
\hline CONSTANT & $\ldots \ldots$ & 13.38112 \\
\hline $\mathrm{R}^{2}$ & 0.521321 & 0.451286 \\
\hline OBSERVATION & 79 & 79 \\
\hline $\mathrm{N}$ & 8 & 8 \\
\hline
\end{tabular}

Source: Authors' Compilation, 2018

Note: All independent variables are differenced to ensure stationarity and thereby avoiding spurious regression while the dependent variable profit is in log form. The level of significance is denoted as $* P<0.1, * * P<0.05$ and $* * * P<0.01$. Figure in the parentheses are (standard error).

\subsection{Panel Regression Result on Total Asset.}

This described the extent of MFBs credit variables' influence on MSEs' growth using total asset as proxy. The result displayed in table 4.5. Table 4.5 showed the panel regression result depicting the extent of microfinance bank credit variables proxy by cost of money, credit period and loan size influence on MSEs' growth, adopting total asset growth as proxy. The pooled OLS result showed a positive marginal impact of loan-size (6.27) and credit period $(0.26)$ on asset whereas cost of money $(-5.21)$ negatively affected the total asset. The loan size was statistically significant $(\mathrm{P}<0.1)$, cost of money statistically significant $(\mathrm{P}<0.05)$ and credit period statistically significant $(\mathrm{P}<0.05)$. The variables combined accounted for $0.582538(58.3 \%)$ of the variation in the total asset as shown by the R-squared value. The adjusted R-squared value was $0.512683(51 \%)$. The Durbin Watson (DW) was 1.264014. This was closed to 2. This explained no sign of autocorrelation. The fixed effect model revealed a positive coefficient value of loan-size (4.21) while credit period (-0.01) and cost of money $(-0.04)$ negatively influenced asset growth. The loan size was statistically significant $(\mathrm{P}<0.01)$, cost of money statistically significant $(\mathrm{P}<0.05)$ and credit period statistically significant $(\mathrm{P}<0.1) .43 .7 \%$ of the variation experienced in the value of asset was accounted for by the bank variables. 
Table 4.5: MFBs credit variables influence MSEs' Growth (Total asset)

\begin{tabular}{lll} 
& ALL & ALL \\
\cline { 2 - 3 } & OLS & FE \\
\cline { 2 - 3 } LOAN SIZE & $6.27 \mathrm{E}-06^{* * *}$ & $4.21 \mathrm{E}-07 * *$ \\
CREDIT PERIOD & $(1.03 \mathrm{E}-06)$ & $(0.21 \mathrm{E}-07)$ \\
& $0.261276^{* *}$ & -0.014351 \\
COST OF MONEY & $(0.068211)$ & $(0.001129)$ \\
& $-5.214521^{* * *}$ & -0.043271 \\
CONSTANT & $(0.121034)$ & $(0.045804)$ \\
R & & 4.142111 \\
OBSERVATION & $\ldots \ldots \ldots \ldots \ldots$ & 0.436824 \\
$\mathrm{~N}$ & 0.582538 & 79 \\
\hline
\end{tabular}

Source: Authors' Compilation, 2018

Note: All independent variables are differenced to ensure stationarity and thereby avoiding spurious regression while the dependent variable profit is in log form. The level of significance is denoted as $* P<0.1, * * P<0.05$ and $* * * P<0.01$. Figure in the parentheses are (standard error).

\section{Findings}

Findings showed that there was a relationship between credit variables and MSE growth indicators with loan size revealing a positive relationship with sales $(\mathrm{r}=0.6991)$, NOE $(\mathrm{r}=0.6194)$, total asset $(\mathrm{r}=0.5873)$ and profit $(\mathrm{r}=$ 0.7422). The average correlation coefficient ( $r$ ) of loan size to MSEs growth was 0.6605 . This underlined the possibility of an increased growth made possible through moderate loan size disbursed by MFBs. The loan was part of the organization additional resources that increased turnover and earnings of MSEs. Findings further revealed that for every increase in loan size there would automatically be an increase sales, asset, NOE and profit. Findings also revealed that cost of money has a negative relationship with sales $(r=-0.5162)$, NOE $(r=-0.5686)$, total asset $(r=-0.6348)$ and profit $(r=-0.4956)$. The average correlation coefficient $(r)$ of cost of money to MSEs growth was $-0.5538(-55.4 \%)$. The study also found out that increase in interest rate could discourage the performance on MSEs activities and lead to stagnated performance.

The study explained the extent of microfinance bank credit variables' influence on MSEs' growth, adopting profit as performance indicator. Findings showed that there was a positive marginal impact of loan-size with coefficient value (8.19) and credit period (2.17) but cost of money (-6.59) has a negative influence on profit performance. For every loan disbursed by MFBs, 8.19 profits would be accrued to MSEs operators for improved business performance. Also for every loan repayment period the profit would increase by 21.7 to micro and small business entrepreneurs and for interest rate, the profits declined by -6.59 . Findings showed that high cost of funds would affect the performance of profit. Findings from the study further revealed that low cost of money could improve performance of MSEs activities resulting to increase in turnover and profit, while high cost of money would lead to stagnated performance. $\mathrm{R}^{2}=0.614035$ with adjusted $\mathrm{R}^{2}=0.591237$ showed that variations in the profit were explained by MFBs variables and all the variables were statistically significant $(\mathrm{p}<0.05)$. Findings further showed that the loan-size (1.30) and credit period (0.14) have significant influence on number of employee growth whereas cost of money (-1.09) negatively affected the employee growth. For every loan disbursed to MSEs operators, it generated 1.3 growth of employees while credit repayment period allowed for 0.14 of employee growth. Also for every interest charged on loan by MFBs attracted a negative -1.09 on employee growth

\subsection{Conclusion and Recommendations}

Microfinance loans provided by MFBs have significant influence on MSEs performance through increase in profit and turnover and while the credit period was regarded as moderate period for loan repayment but the high cost of borrowing associated with the MFBs under review required a holistic approach by regulators and operators. Therefore, considering the extent of influence of MFBs credit variables on MSEs growth, it could be concluded that micro and small businesses profits and sales performance depended on bank loan for business capital growth (business expansion). Furthermore, the relationship between MFBs variables and MSEs growth indices should be strengthened by reducing high interest rate and increasing loan sizes to assist MSEs operators' achieve high profit and turnover. 


\section{References}

Acha, I. (2007). The Role of other Financial Institutions in Economic Development, in Imoh Akpan (ed), Readings in Banking and Finance, 67-84.

Akande, O.O (2014). Entrepreneurial Business Orientation and Economic Survival of Nigerians. International Review of Management and Business Research, 3(2), 1255 - 1259.

Alex, A.K. (2014). Causes and Control of Loan Default/ Delinquency in Microfinance Institutions in Ghana. American International Journal of Contemporary Research, 4(12), 38-44.

Audretsch, D. B. (1995). Innovation and Industry Evolution. Cambridge, Massachusetts: MIT Press

Barbosa, E. G. (2016). Determinants of Small Business Survival: The Case of very Small Enterprises of the Traditional Manufacturing Sectors in Brazil. MPRA Paper No. 72304, July UTC.

Baum, J. A., Calabrese, T., and Silverman, B. S. (2000). Don't Go Alone: Alliance Network Composition and Startups' Performance in Canadian Biotechnology. Strategic Management Journal, 21(3): 267-294.

Bernanke, B. S. (1983). Nonmonetary Effects of the Financial Crisis in the Propagation of the great Depression. American Economic Review, 73(3):257-76.

Besley B. (2008). Essentials of Managerial Finance, (12 ed.). University of Florida: MIT Press.

Bwisa, H.M \& Wanambisi, A.N (2013). Effects of Microfinance Lending on Business Performance: A Survey of Micro and Small Enterprises in Kitale Municipality, Kenya. International Journal of Academic Research in Business and Social Sciences, 3(7), 56-61.

David, W.K., Namwel, B. and George, G. (2014). Impact of Non-Performing Loans on Financial Performance of Microfinance Banks in Kenya: A Survey of Microfinance Banks in Nakuru town. International Journal of Science and Research, 3(10), 2073 -2076.

Dunne, P., and Hughes, A. (1994). Age, Size, Growth and Survival: UK Companies in the 1980s. Journal of Industrial Economics, 42, 115-40.

Gallagher, P.N. (2006). CGAP Report Finds Interest Charges, Along with Costs and Profits, are Declining; IMF Discussion Paper No. 95.

Gaul, S. (2011) Mapping Africa Financial Inclusion Overview. Washington D.C.: Microfinance Information Exchange.

Gonzalez, K., Sushma, N. (2009). The New Money Lenders: Are The Poor Being Exploited By High Microcredit Interest Rates? CGAP. (Online) Available: http://www.mifireport.com/richard rosenberg/andrian gonzalez/sushma (November 2, 2009).

Gordon, R. J. (1988). The Role of Wages in the Inflation Process. American Economic Review, 52: 215 - 226.

Guerin, I., and Palier, J. (2005). Microfinance Challenges: Empowerment or Disempowerment of the poor? Collection Sciences Sociales, Institut Français dePondichéry.

Gujarati N. (2004). Basic Econometrics (4th ed.). New Jersey: McGraw-Hill Companies.

Hajela, T. (2009). Money, Banking and Public Finance, (8th ed.). Ane Books Ltd. New Delhi, India.

Hansen, V. \& Mowen J. (2012). Pengaruh Family Control, Size, Sales Growth, dan Leverage Terhadap Profitabilitas dan Nilai Perusahaan. Jurnal Bisins dan Akuntansi. Universitas Kristen Petra, 4(3), 45 -56.

Hartaska, V. (2005). Governance and Performance of Microfinance Institutions in Central and Eastern Europe and the Newly Independent States. World Development 33(10), 1627-1643.

Hoff K., and Stiglitz, J. (1990). Imperfect Information and Rural Credit Markets: Puzzles and Policy Perspectives. The World Bank Economic Review, 4(3), 235-250.

Kazanjian, R.K., and Drazin, R. (1989). An Empirical Test of Stage of Growth Progression Model. Management Science, 35(12), 1489-1503.

Kibera, J.M. (2012). Factors that Influence Loan Default Rate: A Case of the Micro Finance Firms in Nairobi, Kenya. Journal of Finance and Management, 2(1), 13 -22.

Laetitia, M., Shukla, J. \& Luvanda, A. (2015). Microfinance and Business Growth of Women SMEs in Rwanda (Case of Selected Women Small \& Medium Enterprises in Kicukiro District). European Journal of Accounting, Auditing and Finance Research, 3(11), 26-29.

Liedholm, C. (2002). Small Firm Dynamics: Evidence from Africa and Latin America. Small Business Economics, 18(1-3), 225-242.

Makorere, (2014). The Roles of Microfinance in Promoting SMEs in Tanzania: Empirical Evidence SMEs Holders who have Received Microcredits from Financial Institutions in Marogoro. Global Business and Economics Research Journal, 3 (4), 1 - 19.

Mata, J., and Portugal, P. (1994). Life Duration of New Firms. Journal of Industrial Economics, 42:227-245.

Microfinance Information Exchange -MIX (2009). Micro-Banking Bulletin. Issue 18, Spring 2009. ISSN 19343884

Muktar, M., (2009). The Role of Microfinance Banks in the Promotion and Development of Entrepreneurship in Semi-Urban and Rural Areas. Journal of Entrepreneurship Studies, 4(2), 25 -35.

Multhoni, M.P (2016). Assessing Institutional Characteristics on Microcredit Default in Kenya: A Comparative 
Analysis of Microfinance Institutions and Financial institutions. Journal of Education and Practice, 7(18), $178-190$.

Murphy, G. B., Trailer, J. W., and Hill, R. C. (1996). Measuring Performance in Entrepreneurship Research. Journal of Business Research, 36: 15-23.

Murray, J. (2011). Default on a Loan. United States Business Law and Taxes Guide.

Mushtaque, C. and Mosley, P. (2004). The Social Impact of Microfinance. Journal of International Development, Special Issue, 16 (3), 8 -15.

Nguta, M.H. and Guyo, H.S, (2013). Factors Influencing Loan Repayment Default in Microfinance Institutions. The Experience of Imenti North District, Kenya. International Journal of Applied Sciences and technology, 3(4), 8-10.

Obadeyi, J. A. (2015). Microfinance Banking and Development of Small Business in Emerging Economy: Nigerian Approach. Journal of Economics and Finance, 6(2): 50-60.

Odongo, J. (2014). Lending Terms and Financial Performance of Small Medium Enterprises in Uganda: Case of Soroti District. Research Journal of Finance and Accounting, 5(2), 78 -89.

Okpara, G. (2010). Microfinance Banks and Poverty Alleviation in Nigeria. Journal of Sustainable Development in Africa, 12(6), 177-191.

Oladejo, M.O (2013). Evaluation of the Nigerian Microfinance Banks Credit Administration on Small and Medium Scale Enterprises Operations. International Review of Management and Business Research, 2(2), 505 - 514.

Oladejo, M.O., and Olowookere, J.K. (2011). Automation of Microfinance Institutions in Nigeria: Implication for the Accountants. International Journal of Development and Management Review, 6(1), 3 -6.

Pearson, R. and Greef, M. (2006). Causes of Default among Housing Micro Loan Clients, Finmark Trust Rural Housing Loan Fund. National Housing Finance Corporation and Development Bank of Southern Africa, South Africa.

Rosenberg, R. (2009). Measuring Results of Microfinance Institutions Minimum: Indicators that Donors and Investors Should Track: A Technical Guide. Washington, DC: CGAP.

Schreiner, M. (2002). Aspect of Outreach: A Framework for Discussion of the Social Benefits of Microfinance. Journal of International Development, 14(1), 591-603.

Scott, J. W., and Arias, J. C., (2011). Banking Profitability Determinants. Business Intelligence Journal, 4(2), 209230

Shabbir, M.S. (2016). The Impact of Micro Finance Institutions on Economic Growth of Morocco. Center of Professional Excellence, International Islamic University, Islamabad, Pakistan. Journal of Tourism \& Hospitality, 5(2), $1-5$.

Taiwo, J.N., Onasanya, A.Y., Agwu, M.E and Benson, K.N (2015). The Role of Microfinance Institutions in Financing Small Businesses. Journal of Internet Banking and Commerce, 21(1), 2-20.

Vanroose, A. (2008). What Macro Factors Make Microfinance Institutions Reach Out? Center for European Research in Microfinance, Solvay Business School; Université LibredeBruxelles http://www.solvay.edu/EN/Research/Bernheim/documents/wp08036.pdf

Venkatraman, N., and Ramanujam, V. (1987). Measurement of Business Economic Performance: An Examination of Method Convergence. Journal of Management, 13(1): 109-122.

Wadhwani, S. B. (1986). Inflation, Bankruptcy, Default Premia and the Stock Market. The Economic Journal, 96 (381), 120-138.

Wanjohi, A.M., and Mugure, A. (2008). Factors Affecting the Growth of MSEs in Rural Areas of Kenya: A Case of ICT Firms in Kiserian Township, Kajiado District of Kenya. Journal of Management, 3(2), 34 -42.

Warue, B.N., (2012). Factors Affecting Loan Delinquency in Microfinance in Kenya. International Journal of Management Sciences and Business Research, 1(2), 3 - 9.

Wellen, H., and Mulder, A. (2008). Micro Credits in SMEs. Journal of Finance and Microfinance, 7: 122-34

Wole Adamolekun (1993). Community Banking System: Modernizing the Informal Financial intermediaries in Nigeria. Innovative Banking Monograph Series, 1: 8 - 30

Yang, X. J. (2005). Survival Analysis of Small and Medium-Sized Firms: Shenzhen Stock Exchange. Working papers series. 


\begin{tabular}{|c|c|c|c|c|c|c|c|}
\hline \multicolumn{8}{|c|}{$\begin{array}{l}\text { APPENDICES } \\
\text { APPENDIX A } \\
\text { CORRELATION MATRIX }\end{array}$} \\
\hline Correlation & & & & & & & \\
\hline Probability & SALES & PROFIT & NOE & ASSET & LOAN_SI & CRE_PE & COST-M \\
\hline SALES & $\begin{array}{r}1.0000 \\
----\end{array}$ & & & & & & \\
\hline PROFIT & $\begin{array}{c}0.5330^{* *} \\
(0.0143)\end{array}$ & $\begin{array}{r}1.0000 \\
-----\end{array}$ & & & & & \\
\hline NOE & $\begin{array}{l}0.6241 * * * \\
(0.0000)\end{array}$ & $\begin{array}{l}0.6499 \\
(0.0553)\end{array}$ & $\begin{array}{r}1.0000 \\
-----\end{array}$ & & & & \\
\hline ASSET & $\begin{array}{l}0.6141 * * * \\
(0.0002)\end{array}$ & $\begin{array}{l}0.5601 \\
(0.0794)\end{array}$ & $\begin{array}{c}0.3328 * * \\
(0.0133)\end{array}$ & $\begin{array}{r}1.0000 \\
----\end{array}$ & & & \\
\hline LOAN_SIZE & $\begin{array}{l}0.6691 * * \\
(0.0305)\end{array}$ & $\begin{array}{c}0.5422 * * \\
(0.0390)\end{array}$ & $\begin{array}{c}0.6194 * * \\
(0.0267)\end{array}$ & $\begin{array}{c}0.5823 * * \\
(0.0254)\end{array}$ & $\begin{array}{c}1.0000 \\
----\end{array}$ & & \\
\hline CREDIT PERIOD & $\begin{array}{l}0.5200 * * \\
(0.0232)\end{array}$ & $\begin{array}{l}0.6117 * * \\
(0.0121)\end{array}$ & $\begin{array}{r}0.5517 * * \\
(0.0222)\end{array}$ & $\begin{array}{c}0.6323 * * \\
(0.0167)\end{array}$ & $\begin{array}{c}-0.2356^{* *} \\
(0.0321)\end{array}$ & $\begin{array}{c}1.0000 \\
---\end{array}$ & \\
\hline COST_OF_MONE & $\begin{array}{l}-0.5162 * * \\
(0.0214)\end{array}$ & $\begin{array}{r}-0.4956^{* *} \\
(0.0443)\end{array}$ & $\begin{array}{l}-0.5686^{* *} \\
(0.0217)\end{array}$ & $\begin{array}{c}-0.6348 * * \\
(0.0156)\end{array}$ & $\begin{array}{c}0.4673 * * \\
(0.0215)\end{array}$ & $\begin{array}{c}0.5418 * * * \\
(0.0001)\end{array}$ & $\begin{array}{r}1.0000 \\
---\end{array}$ \\
\hline
\end{tabular}

The level of significance is denoted as $* P<0.1, * * P<0.05$ and $* * * P<0.01$. Figure in the parentheses are $(P$ values).

\section{APPENDIX B}

POOLED REGRESSION FOR PROFIT AS DEPENDENT VARIABLE

Dependent Variable: LOG(PROFIT?)

Method: Pooled Least Squares

Date: 03/19/18 Time: 04:29

Sample (adjusted): 20082016

Included observations: 9 after adjustments

Cross-sections included: 8

Total pool (unbalanced) observations: 71

\begin{tabular}{lrrrr}
\hline \hline \multicolumn{1}{c}{ Variable } & Coefficient & Std. Error & t-Statistic & Prob. \\
\hline \hline D(LOAN_SIZE?) & $8.19 \mathrm{E}-06$ & $1.76 \mathrm{E}-06$ & 4.649529 & 0.0000 \\
D(CP?) & 2.173114 & 0.073591 & -2.352395 & 0.0216 \\
D(CM?) & -6.590040 & 1.168929 & 5.637675 & 0.0000 \\
\hline \hline R-squared & 0.614035 & Mean dependent var & 11.85996 \\
Adjusted R-squared & 0.591237 & S.D. dependent var & 1.038833 \\
S.E. of regression & 8.156122 & Akaike info criterion & 7.076749 \\
Sum squared resid & 4523.518 & Schwarz criterion & 7.172356 \\
Log likelihood & -248.2246 & Hannan-Quinn criter. & 7.114769 \\
Durbin-Watson stat & 1.382144 & & \\
\hline \hline
\end{tabular}




\section{FIXED EFFECT (PROFIT)}

Dependent Variable: LOG(PROFIT?)

Method: Pooled Least Squares

Date: 03/19/18 Time: 05:06

Sample (adjusted): 20082016

Included observations: 9 after adjustments

Cross-sections included: 8

Total pool (unbalanced) observations: 71

\begin{tabular}{|c|c|c|c|c|}
\hline Variable & Coefficient & Std. Error & t-Statistic & Prob. \\
\hline $\mathrm{C}$ & 11.68149 & 0.087236 & 133.9060 & 0.0000 \\
\hline D(LOAN_SIZE?) & $5.48 \mathrm{E}-07$ & $1.61 \mathrm{E}-07$ & 3.405953 & 0.0012 \\
\hline $\mathrm{D}(\mathrm{C} \overline{\mathrm{P}} ?)$ & 0.033930 & 0.004255 & 0.923535 & 0.0194 \\
\hline $\mathrm{D}(\mathrm{CM} ?)$ & 0.082034 & 0.079560 & 1.031093 & 0.0066 \\
\hline \multicolumn{5}{|l|}{ Fixed Effects (Cross) } \\
\hline KARIS-C & -0.627892 & & & \\
\hline MW-C & -1.098380 & & & \\
\hline EMERALD - C & -0.913397 & & & \\
\hline OLIVE-C & 0.698007 & & & \\
\hline FŌRESIGHT-C & -0.206447 & & & \\
\hline NPF-C & 0.098548 & & & \\
\hline$\overline{\mathrm{ACCION}-\mathrm{C}}$ & 0.423625 & & & \\
\hline \multirow[t]{2}{*}{ _AZSA--C } & 1.556169 & & & \\
\hline & \multicolumn{3}{|c|}{ Effects Specification } & \\
\hline \multicolumn{5}{|c|}{ Cross-section fixed (dummy variables) } \\
\hline R-squared & 0.476738 & Mean dependent var & & 11.85996 \\
\hline Adjusted R-squared & 0.400357 & S.D. dependent var & & 1.038833 \\
\hline S.E. of regression & 0.452391 & Akaike info criterion & & 1.392984 \\
\hline Sum squared resid & 12.27946 & Schwarz criterion & & 1.743540 \\
\hline Log likelihood & -38.45093 & Hannan-Quinn criter. & & 1.532389 \\
\hline F-statistic & 30.91147 & Durbin-Watson stat & & 1.278223 \\
\hline Prob(F-statistic) & 0.000000 & & & \\
\hline
\end{tabular}

\section{POOLED REGRESSION FOR ASSET}

Dependent Variable: LOG(ASSET?)

Method: Pooled Least Squares

Date: 03/19/18 Time: 04:45

Sample (adjusted): 20082016

Included observations: 9 after adjustments

Cross-sections included: 8

Total pool (unbalanced) observations: 71

\begin{tabular}{lrlrr}
\hline \hline \multicolumn{1}{c}{ Variable } & Coefficient & Std. Error & t-Statistic & Prob. \\
\hline \hline D(LOAN_SIZE?) & $6.27 \mathrm{E}-06$ & $1.03 \mathrm{E}-06$ & 3.015240 & 0.0632 \\
D(CP?) & 0.261101 & 0.068211 & -1.503560 & 0.0365 \\
D(CM?) & -5.214521 & 0.121034 & 4.023421 & 0.0281 \\
\hline \hline R-squared & 0.582538 & Mean dependent var & & 1.983694 \\
Adjusted R-squared & 0.512683 & S.D. dependent var & & 0.698317 \\
S.E. of regression & 1.607154 & Akaike info criterion & & 3.392141 \\
Sum squared resid & 121.4813 & Schwarz criterion & & 3.534294 \\
Log likelihood & -128.2201 & Hannan-Quinn criter. & & 3.132260 \\
Durbin-Watson stat & 1.264014 & & \\
\hline \hline
\end{tabular}




\section{FIXED EFFECT (ASSET)}

Dependent Variable: LOG (Asset?)

Method: Pooled Least Squares

Date: 03/19/18 Time: 04:52

Sample (adjusted): 20082016

Included observations: 9 after adjustments

Cross-sections included: 8

Total pool (unbalanced) observations: 71

\begin{tabular}{|c|c|c|c|c|}
\hline Variable & Coefficient & Std. Error & t-Statistic & Prob. \\
\hline $\mathrm{C}$ & 4.142111 & 0.091878 & 15.22512 & 0.0000 \\
\hline D(LOAN_SIZE?) & $4.21 \mathrm{E}-07$ & $0.69 \mathrm{E}-07$ & 2.440923 & 0.0000 \\
\hline $\mathrm{D}(\mathrm{C} \overline{\mathrm{P}} ?)$ & -0.014000 & 0.001129 & -1.970648 & 0.0511 \\
\hline $\mathrm{D}(\mathrm{CM} ?)$ & -0.043271 & 0.045804 & 1.159815 & 0.2388 \\
\hline \multicolumn{5}{|l|}{ Fixed Effects (Cross) } \\
\hline KARIS-C & 0.631726 & & & \\
\hline${ }_{-} \mathrm{MW}-\mathrm{C}$ & -0.520115 & & & \\
\hline EM̄̄ERALD--C & 0.383538 & & & \\
\hline${ }^{-}$OLIVE--C & 0.011511 & & & \\
\hline _FŌRESIGHT--C & 0.038924 & & & \\
\hline${ }_{-} \mathrm{NPF}-\mathrm{C}$ & -0.233498 & & & \\
\hline$\overline{\mathrm{CCION}--\mathrm{C}}$ & -0.118345 & & & \\
\hline _AZSA--C & 0.159226 & & & \\
\hline \multicolumn{5}{|c|}{ Effects Specification } \\
\hline \multicolumn{5}{|c|}{ Cross-section fixed (dummy variables) } \\
\hline R-squared & 0.436824 & Mean dependent var & & 1.482194 \\
\hline Adjusted R-squared & 0.414471 & S.D. dependent var & & 0.528117 \\
\hline S.E. of regression & 0.476460 & Akaike info criterion & & 1.136643 \\
\hline Sum squared resid & 13.62084 & Schwarz criterion & & 1.745513 \\
\hline Log likelihood & -42.13132 & Hannan-Quinn criter. & & 1.446561 \\
\hline F-statistic & 9.036656 & Durbin-Watson stat & & 1.312124 \\
\hline Prob(F-statistic) & 0.000000 & & & \\
\hline
\end{tabular}

\section{POOLED REGRESSION FOR NOE}

Dependent Variable: LOG(NOE?)

Method: Pooled Least Squares

Date: 03/19/18 Time: 04:45

Sample (adjusted): 20082016

Included observations: 9 after adjustments

Cross-sections included: 8

Total pool (unbalanced) observations: 71

\begin{tabular}{lrrrr}
\hline \multicolumn{1}{c}{ Variable } & Coefficient & Std. Error & t-Statistic & Prob. \\
\hline \hline \multicolumn{1}{c}{ D(LOAN_SIZE?) } & $1.30 \mathrm{E}-06$ & $3.25 \mathrm{E}-07$ & 4.005840 & 0.0432 \\
D(CP?) & 0.138103 & 0.013576 & -2.806590 & 0.0015 \\
D(CM?) & -1.087527 & 0.215646 & 5.043111 & 0.0054 \\
\hline \hline R-squared & 0.481044 & Mean dependent var & 1.983694 \\
Adjusted R-squared & 0.442681 & S.D. dependent var & 0.698317 \\
S.E. of regression & 1.504656 & Akaike info criterion & 3.696341 \\
Sum squared resid & 153.9513 & Schwarz criterion & 3.791947 \\
Log likelihood & -128.2201 & Hannan-Quinn criter. & 3.734360 \\
Durbin-Watson stat & 1.324022 & & \\
\hline \hline
\end{tabular}




\section{FIXED EFFECT (NOE)}

Dependent Variable: LOG(NOE?)

Method: Pooled Least Squares

Date: 03/19/18 Time: 04:52

Sample (adjusted): 20082016

Included observations: 9 after adjustments

Cross-sections included: 8

Total pool (unbalanced) observations: 71

\begin{tabular}{|c|c|c|c|c|}
\hline Variable & Coefficient & Std. Error & t-Statistic & Prob. \\
\hline $\mathrm{C}$ & 1.678204 & 0.091878 & 18.26562 & 0.0000 \\
\hline D(LOAN_SIZE?) & 7.61E-07 & 1.69E-07 & 4.490933 & 0.0100 \\
\hline $\mathrm{D}(\mathrm{C} \overline{\mathrm{P}} ?)$ & 0.008923 & 0.004482 & -1.990898 & 0.0511 \\
\hline D(CM?) & -0.099709 & 0.083793 & 1.189945 & 0.0288 \\
\hline \multicolumn{5}{|l|}{ Fixed Effects (Cross) } \\
\hline KARIS-C & 0.831716 & & & \\
\hline MW-C & -0.550255 & & & \\
\hline EM̄ERALD--C & 0.685528 & & & \\
\hline OLIVE--C & 0.031036 & & & \\
\hline FŌRESIGHT--C & 0.037936 & & & \\
\hline NPF-C & -0.673468 & & & \\
\hline$\overline{\mathrm{ACCION}-\mathrm{C}}$ & -0.868348 & & & \\
\hline \multirow[t]{2}{*}{ AZSA--C } & 0.598268 & & & \\
\hline & \multicolumn{3}{|c|}{ Effects Specification } & \\
\hline \multicolumn{5}{|c|}{ Cross-section fixed (dummy variables) } \\
\hline R-squared & 0.600975 & Mean dependent var & & 1.983694 \\
\hline Adjusted R-squared & 0.534471 & S.D. dependent var & & 0.698317 \\
\hline S.E. of regression & 0.476460 & Akaike info criterion & & 1.496657 \\
\hline Sum squared resid & 13.62084 & Schwarz criterion & & 1.847213 \\
\hline Log likelihood & -42.13132 & Hannan-Quinn criter. & & 1.636062 \\
\hline F-statistic & 9.036656 & Durbin-Watson stat & & 1.152770 \\
\hline Prob(F-statistic) & 0.000000 & & & \\
\hline
\end{tabular}

POOLED REGRESSION LOG OF SALES

Dependent Variable: LOG(SALES?)

Method: Pooled Least Squares

Date: 03/19/18 Time: 05:29

Sample (adjusted): 20082016

Included observations: 9 after adjustments

Cross-sections included: 8

Total pool (unbalanced) observations: 71

\begin{tabular}{lrlrr}
\hline \hline \multicolumn{1}{c}{ Variable } & Coefficient & Std. Error & t-Statistic & Prob. \\
\hline \hline D(LOAN_SIZE?) & $8.37 \mathrm{E}-06$ & $2.07 \mathrm{E}-06$ & 4.043856 & 0.0211 \\
D(CP?) & 0.214279 & 0.086566 & -2.475310 & 0.0158 \\
D(CM?) & -7.529366 & 1.375039 & 5.475748 & 0.0774 \\
\hline \hline R-squared & 0.521321 & Mean dependent var & & 13.51994 \\
Adjusted R-squared & 0.487351 & S.D. dependent var & & 1.232003 \\
S.E. of regression & 9.594242 & Akaike info criterion & & 7.401538 \\
Sum squared resid & 6259.365 & Schwarz criterion & & 7.497144 \\
Log likelihood & -259.7546 & Hannan-Quinn criter. & & 7.439558 \\
Durbin-Watson stat & 1.342486 & & \\
\hline \hline
\end{tabular}


Random effect

Dependent Variable: LOG(SALES?)

Method: Pooled EGLS (Cross-section random effects)

Date: 03/19/18 Time: 05:47

Sample (adjusted): 20082016

Included observations: 9 after adjustments

Cross-sections included: 8

Total pool (unbalanced) observations: 71

Swamy and Arora estimator of component variances

\begin{tabular}{crrrr}
\hline \hline Variable & Coefficient & Std. Error & t-Statistic & Prob. \\
\hline \hline C & 13.38112 & 0.427798 & 31.27904 & 0.0000 \\
D(LOAN_SIZE?) & $4.83 \mathrm{E}-07$ & $1.55 \mathrm{E}-07$ & 3.108790 & 0.0028 \\
D(CP?) & -0.005953 & 0.004147 & -1.435439 & 0.0558 \\
D(CM?) & -0.006991 & 0.077509 & -0.090198 & 0.0684 \\
Random Effects (Cross) & & & \\
-KARIS--C & 1.486621 & & \\
_-EMW--C & -1.411726 & & \\
E-OLRALD--C & -1.174705 & & \\
- FORESIGHT--C & 0.609883 & & \\
NPF--C & 1.372743 & & \\
ACCION--C & -0.391134 & & \\
_AZSA--C & -1.435354 & & & \\
\hline \hline
\end{tabular}

Effects Specification

$$
\text { S.D. }
$$

\begin{tabular}{llr}
\hline \hline Cross-section random & 1.186165 & 0.8786 \\
Idiosyncratic random & 0.440881 & 0.1214 \\
\hline
\end{tabular}

Weighted Statistics

\begin{tabular}{llll}
\hline R-squared & 0.451286 & Mean dependent var & 1.674681 \\
Adjusted R-squared & 0.413284 & S.D. dependent var & 0.476781 \\
S.E. of regression & 0.443885 & Sum squared resid & 13.20127 \\
F-statistic & 3.980987 & Durbin-Watson stat & 1.008702 \\
Prob(F-statistic) & 0.011350 & &
\end{tabular}

Unweighted Statistics

R-squared

-0.044634 Mean dependent var

13.51994

Sum squared resid

110.9906 Durbin-Watson stat

0.119975 